Y. YIN, Y. DAI, H. JIA, J. LI, L. BU, B. QIAO, X. ZHAO, Z. JIANG* (HENAN UNIVERSITY AND HENAN UNIVERSITY OF TECHNOLOGY, P. R. OF CHINA)

Conjugate Addition-Enantioselective Protonation of $N$-Aryl Glycines to $\alpha$-Branched 2-Vinylazaarenes via

Cooperative Photoredox and Asymmetric Catalysis

J. Am. Chem. Soc. 2018, 140, 6083-6087.

\section{Cooperative Catalysis: Radical Addition to Olefins and Asymmetric Protonation}

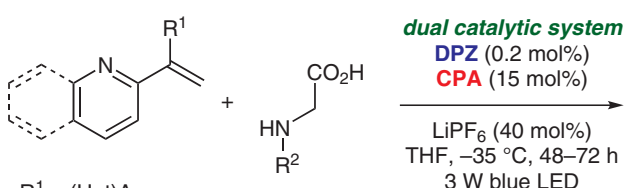

$\mathrm{R}^{2}=\mathrm{Ar}$

Selected examples:<smiles>c1ccc(NCCC(c2ccccc2)c2ccccn2)cc1</smiles>

$\stackrel{\mathrm{P}}{\mathrm{Ph}}$

$87 \%$ yield<smiles>Clc1ccc([C@H](CCNc2ccccc2)c2ccccn2)cc1</smiles>

$83 \%$ yield

er $=94: 6$<smiles>CC(C)(C)NCCC(c1ccccc1)c1ccccn1</smiles>

(PMP $=$ para-methoxyphenyl) $83 \%$ yield er $=95.5: 4.5$ 1. PMP deprotection 2. reductive amination

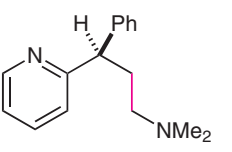

(R)-pheniramine (antihistamine drug) $76 \%$ yield (over two steps) er $=95.5: 4.5$

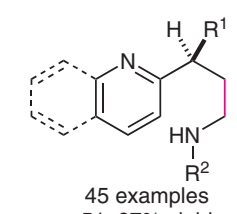
$3 \mathrm{~W}$ blue LED

$51-97 \%$

er from 83.5:16.5 to >99.5:0.5<smiles>O=S(=O)(NCCC(c1ccccc1)c1ccc2ccccc2n1)Oc1ccccc1</smiles>

$69 \%$ yield
er $=96.5: 3.5$

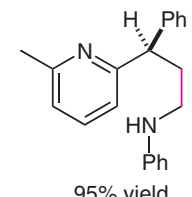

$95 \%$ yield
Gategory

Organo- and

Biocatalysis

\section{Key words}

enantioselective protonation

conjugate addition

cooperative

catalysis

azaarenes

Proposed mechanism:

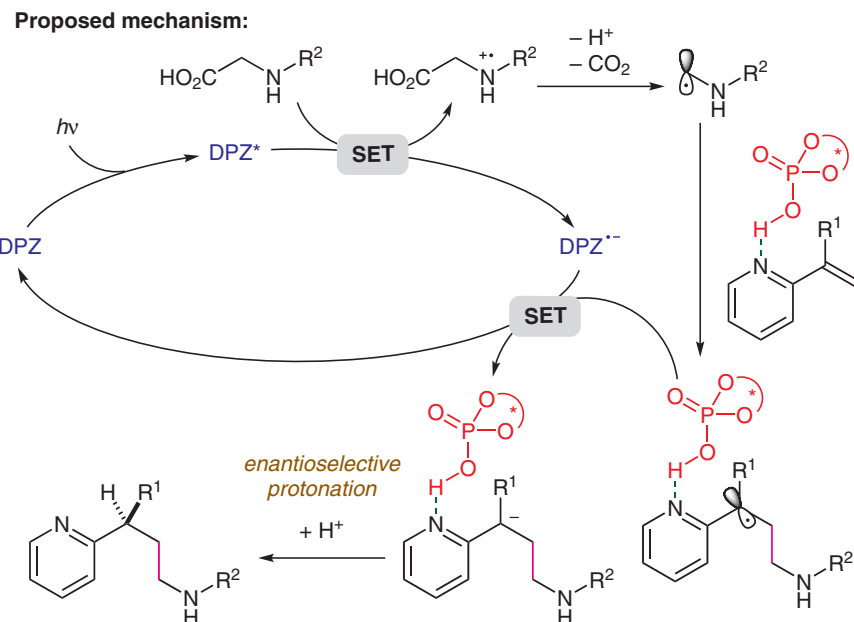

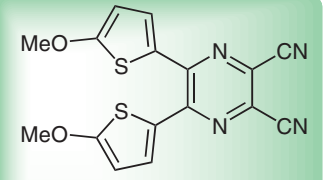

DPZ

(photosensitizer)

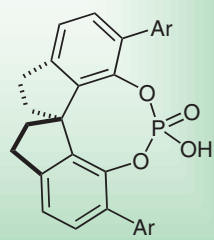

CPA

$\left(\mathrm{Ar}=2-\mathrm{CF}_{3} \mathrm{C}_{6} \mathrm{H}_{4}\right.$ or 2-Naph)
Significance: Jiang and co-workers report the enantioselective radical conjugate additionprotonation of $N$-aryl glycines to $\alpha$-branched vinylazaarenes using a metal-free dual catalytic system (a photosensitizer and a chiral phosphoric acid). The corresponding products are obtained in high yields with good to excellent enantioselectivities, and the methodology is applied to the synthesis of the medicinal compound pheniramine.

SYNFACTS Contributors: Benjamin List, David Díaz-Oviedo

Synfacts 2018, 14(07), 0753 Published online: 18.06.2018 DoI: 10.1055/s-0037-1610083; Reg-No.: B05118SF

Comment: Because $\alpha$-amino acids are abundant, their use as starting materials for organic synthesis is desirable. In this report, $N$-aryl $\alpha$-glycines undergo photooxidative decarboxylation and react further with highly activated olefins in a radical pathway followed by enantioselective protonation. While many examples are shown, the presented substrate scope is still limited to pyridine- and quinoline-containing substances. 